\title{
BIOMASSA DAN KANDUNGAN KLOROFIL TOTAL DAUN JAHE (Zingiber officinale L.) YANG MENGALAMI CEKAMAN KEKERINGAN
}

\author{
Nio Song $\mathbf{A} \mathbf{i}^{1)}$ \\ email: nio_ai@yahoo.com \\ ${ }^{1)}$ Program Studi Biologi FMIPA Universitas SamRatulangi Manado, 95115
}

\begin{abstract}
ABSTRAK
Telah dilakukan penelitian untuk mempelajari pengaruh cekaman kekeringan terhadap biomassa dan kandungan klorofil total daun pada jahe (Zingiber officinale L.). Penelitian ini dilakukan dalam Rancangan Acak Lengkap dengan 2 perlakuan dalam 3 ulangan. Tanaman jahe dengan 5 helai daun yang ditanam dalam polybag disirami sampai kapasitas lapang (kontrol) dan tidak disirami (kekeringan) selama 7 hari. Biomassa dan kandungan klorofil total daun diukur sebelum perlakuan kekeringan dimulai (hari ke-0) dan 7 hari setelah perlakuan kekeringan (hari ke-7). Pertambahan biomassa daun pada tanaman jahe kontrol 54\% lebih besar daripada tanaman jahe yang mengalami kekeringan selama7 hari. Kekeringan selama 7 hari menurunkan kandungan klorofil total daun jahe.
\end{abstract}

Kata kunci: biomassa, cekaman kekeringan, kandungan klorofil total

\section{BIOMASS AND CONCENTRATION OF TOTAL CHLOROPHYLL ON GINGER (Zingiber Officinale L.) LEAF UNDER WATER DEFICIT}

\begin{abstract}
The effect of water deficit on biomass and concentration of total chlorophyll was studied on ginger (Zingiber officinale L.) leaf. The experiment consisted of 1 cultivars grown in 2 water regimes, with 3 replicates, in a randomized complete block design. The two water regimes were well-watered (watered until field capacity) and water deficit obtained by withholding water on 5leaf-ginger plants during 7 days. Biomass and concentration of total chlorophyll on ginger leaf were measured before water deficit treatment commenced (day 0) and 7 days after water deficit treatment (day 7). The increase of leaf biomass in control plants was $54 \%$ higher than in waterdeficit plants and leaf total chlorophyll decreased $8 \%$ after 7-day-water-deficit.
\end{abstract}

Keywords: biomass, total chlorophyll, water-deficit

\section{PENDAHULUAN}

Lingkungan yang ekstrim ialah
lingkungan yang dapat menimbulkan cekaman pada tumbuhan. Penyebab cekaman dapat berupa berbagai bahan kimia dan faktor-faktor fisik yang bersifat permanen maupun dapat balik. Kekeringan dapat merupakan cekaman primer maupun cekaman sekunder. Cekaman primer disebabkan oleh kekurangan air di lingkungan sekitar tumbuhan, sedangkan cekaman sekunder diinduksi oleh keadaan dingin, pembekuan, panas atau kadar garam. Sel tumbuhan yang telah kehilangan air dan mempunyai tekanan turgor yang lebih rendah daripada nilai maksimumnya dikatakan mengalami cekaman kekeringan (Darusman et al., 1991; Tal, 1983; Fitter dan Hay, 1994).
Cekaman kekeringan pada tanaman menunjukkan kekurangan air yang dialami oleh tanaman akibat keterbatasan air dari lingkungannya, yaitu media tanam (Bray, 1997). Cekaman air pada tanaman dapat disebabkan oleh kekurangan suplai air di daerah perakaran. Di samping itu permintaan air yang berlebihan oleh daun akibat laju evapotranspirasi melebihi laju absorpsi air walaupun ketersediaan air tanah cukup juga mengakibatkan cekamn kekeringan. Oleh sebab itu laju transpirasi, sistem perakaran dan ketersediaan air tanah mempengaruhi serapan air oleh akar tanaman (Lakitan, 1996; Bray, 1997).

Respons tanaman yang mengalami cekaman kekeringan dapat merupakan perubahan di tingkat selular dan molekular yang ditunjukkan dengan penurunan laju 
pertumbuhan, berkurangnya luas daun dan peningkatan rasio akar : tajuk. Tingkat kerugian tanaman akibat kekeringan dipengaruhi oleh beberapa faktor, antara lain intensitas kekeringan yang dialami, lamanya kekeringan dan tahap pertumbuhan saat tanaman mengalami kekeringan (Srivastata $e t$ al., 1994; Upadhyaya, 1994; Nio dan Kandou, 2000). Jika mengalami kekeringan, dua macam respons tanaman yang dapat memperbaiki status air adalah (1) mengubah distribusi asimilat baru untuk lebih mendukung pertumbuhan akar daripada tajuk, sehingga dapat meningkatkan kapasitas akar menyerap air serta menghambat pertumbuhan tajuk untuk mengurangi transpirasi dan (2) mengatur derajat pembukaan stomata untuk menghambat hilangnya air melalui transpirasi (Mansfield, 1990).

Cekaman kekeringan dari tingkat paling ringan sampai paling berat mempengaruhi proses-proses bioimia yang berlangsung dalam sel. Kekeringan mempengaruhi reaksi-reaksi biokimia fotosintesis, sehingga laju fotosintesis menurun. Salah satu aspek fotosintesis yang sangat sensitif terhadap cekaman kekeringan, termasuk cekaman tingkat ringan, ialah biosintesis klorofil (Fitter dan Hay, 1994). Di samping itu pembentukan protoklorofil terhambat pada potensial air sedikit di bawah 0 atm (Salisbury dan Ross, 1992).

Pengaruh cekaman kekeringan terhadap pertumbuhan dan hasil produksi telah dilakukan pada berbagai tanaman, tetapi penelitian sejenis pada tanaman obat masih kurang dilakukan. Kekeringan pada basil manis (Ociumum basilicum) menurunkan tinggi tanaman dan luas daun serta meningkatkan rasio akar : tajuk (Lebaschi et al., 2003). Kekeringan pada mint (Mentha sp.) mengurangi luas daun, berat basah dan berat kering (Misra dan Sricastatva, 2000). Informasi tentang pengaruh kekeringan pada tanaman obat yang banyak dimanfaatkan di Indonesia, seperti jahe (Zingiber officinale L.) masih kurang. Jahe merupakan jenis rempah-rempah yang paling banyak digunakan dan sebagai tanaman obat dapat dipakai sebagai obat masuk angin, gangguan pencernaan, antipiretik (Kikuzaki dan Nakatani, 1993). Untuk lebih memperkaya wawasan tentang respons tanaman obat terhadap kekeringan, penelitian ini mengevaluasi biomassa dan kandungan klorofil total daun jahe yang mengalami kekeringan.

\section{METODE PENELITIAN}

Penelitian ini dilakukan dalam Rancangan Acak Lengkap dengan 2 perlakuan dan 3 kali ulangan di kebun percobaan Jurusan Biologi FMIPA UNSRAT selama 8 minggu. Bahan penelitian yang digunakan ialah rimpang jahe yang diperoleh dari pasar tradisional. Variabel bebas dalam penelitian ini adalah perlakuan cekaman kekeringan, yaitu disirami sampai kapasitas lapang (kontrol) dan tidak disirami (kekeringan). Sedangkan variabel terikatnya adalah biomassa daun dan kandungan klorofil total daun, yang diamati setelah 1 minggu perlakuan.

Tahapan kerja dalam penelitian ini meliputi pertunasan rimpang jahe, pemeliharaan tanaman, pemberian cekaman kekeringan dan pengambilan sampel daun untuk dianalisis biomassa dan kandungan klorofil totalnya. Rimpang jahe dengan mata tunas ditanam di media tanah dalam gelas plastik dan dipelihara sampai tumbuh tunas dengan 5 helai daun. Tanaman muda dengan 5 helai daun dipindahkan ke polybag yang berisi tanah kira-kira $2 \mathrm{~kg}$ dan dipelihara selama 7 hari dengan cara disirami setiap hari sebelum cekaman kekeringan diperlakukan. Tanaman kontrol diairi sampai kapasitas lapang setiap 2 hari, sedangkan tanaman perlakuan kekeringan tidak diairi selama 7 hari. Sampel daun diambil pada hari ke-0 (sebelum perlakuan dimulai) dan hari ke-7 (7 hari setelah perlakuan kekeringan). Biomassa daun diperoleh dengan menimbang sampel daun yang telah dikeringkan dengan oven pada temperatur $70^{\circ} \mathrm{C}$ selama $2 \times 24$ jam. Kandungan klorofil total daun ditentukan dengan menggunakan spektrofotometer setelah klorofil diekstrak dengan alkohol 95\% (modifikasi dari Sasmitamihardja, 1990). Sebagai data penunjang, evapotranspirasi diukur dengan cara menimbang polybag yang berisi tanah dan tanaman, baik pada kontrol maupun perlakuan selama perlakuan kekeringan. Data dianalisis dengan uji t 5\%. 


\section{HASIL DAN PEMBAHASAN}

Air sangat diperlukan dalam siklus hidup tanaman dan proses metabolisme tanaman tidak dapat berlangsung tanpa adanya air. Air dapat masuk ke dalam sel tanaman melalui tanah dengan jalan penyerapan oleh akar. Kemampuan partikel tanah menahan air dan kemampuan akar untuk menyerap air menentukan kadar air dalam tanah dan banyaknya air yang diserap oleh akar tanaman (Jumin, 1992; Nio et al., 2010). Cekaman kekeringan akan mengurangi pertumbuhan akar dan bagian tanaman di atas permukaan tanah, menurunkan luas daun dan berat kering, mengurangi laju fotosintesis dan transpirasi serta merusak asam amino, enzim dan protein lainnya (Pugnaire et al., 1999).

\section{Biomassa Daun Jahe yang Mengalami Kekeringan}

Cekaman kekeringan yang ringan pada tanaman dapat menurunkan laju pertumbuhan tanaman pada fase vegetatif. Pertumbuhan pada fase vegetatif mencakup pertumbuhan akar, batang dan daun. Pada fase ini tanaman memerlukan banyak cadangan makanan yang akan diubah menjadi energi untuk pertumbuhan. Kekurangan air pada fase vegetatif mengakibatkan daun-daun menjadi lebih kecil (Gardner et al., 1991; Saptarani, 1999).

Biomassa daun jahe pada tanaman kontrol dan yang mengalami kekeringan bertambah setelah 7 hari perlakuan (Tabel 1). Pertambahan biomassa daun pada tanaman kontrol 54\% lebih besar daripada tanaman yang mengalami kekeringan berdasarkan uji $\mathrm{t}$ 5\% yang ditunjukkan oleh nilai $\mathrm{t}$ hitung $(5,787)$ yang lebih besar daripada nilai t tabel $0,05(4,303)$.

Tabel 1. Biomassa daun (g) pada jahe pada hari ke-0 dan 7 hari setelah mengalami kekeringan (rata-rata \pm standard deviasi)

\begin{tabular}{rlc}
\hline $\begin{array}{l}\text { Hari } \\
\text { ke- }\end{array}$ & Kontrol & Kekeringan \\
\hline 0 & $0,1496 \pm 0,0126$ & - \\
7 & $0,1945 \pm 0,009$ & $0,1788 \pm 0,034$ \\
\hline
\end{tabular}

Kekeringan mempengaruhi pertumbuhan tanaman, yaitu berkurangnya pertumbuhan akar, batang dan daun karena fotosintesis dan transpirasi terganggu akibat rusaknya asam amino, enzim dan protein yang berperan dalam kedua proses tersebut (Pugnaire et al., 1999). Hasil penelitian ini menunjukkan bahwa kekeringan menurunkan pertambahan biomassa daun jahe seperti halnya pada Mentha sp. (Misra dan Sricastatva, 2000). Berkurangnya ukuran tanaman pada saat kekeringan menguntungkan bagi tanaman karena kondisi tersebut mengurangi penggunaan air oleh tanaman dan kerusakan jaringan tanaman (Blum, 1996; 2005; Nio, 2009).

\section{Kandungan Klorofil Daun Jahe yang Mengalami Kekeringan}

Klorofil merupakan sebagian besar pigmen yang ditemukan dalam membran tilakoid kloroplas. Pigmen hijau daun ini berperan mengabsorpsi cahaya dalam fotosintesis fase I, yaitu reaksi fotolisis (Salisbury dan Ross, 1992). Kandungan klorofil total daun menurun $8 \%$ akibat kekeringan pada tanaman jahe selama 7 hari, sedangkan kandungan klorofil total daun pada tanaman kontrol meningkat $9 \%$ dari hari ke-0 sampai hari ke-7 (Tabel 2). Oleh sebab itu uji t tidak dilakukan.

Tabel 2. Kandungan klorofil total daun (mg/L) pada jahe pada hari ke-0 dan 7 hari setelah mengalami kekeringan (rata-rata \pm standard deviasi)

\begin{tabular}{clc}
\hline $\begin{array}{l}\text { Hari } \\
\text { ke- }\end{array}$ & Kontrol & Kekeringan \\
\hline 0 & $29,10 \pm 0,65$ & - \\
7 & $31,74 \pm 0,40$ & $26,92 \pm 2,19$ \\
\hline
\end{tabular}

Seperti halnya hasil penelitian ini, kandungan klorofil total dan klorofil a pada daun padi yang mengalami kekeringan dengan induksi polietilen glikol (potensial air $-1,0$ atm) juga lebih kecil daripada padi kontrol (Nio, 2010). Hal ini disebabkan karena cekaman kekringan dari tingkat ringan sampai berat mempengaruhi reaksi-reaksi biokimia fotosintesis, sehingga laju fotosintesis menurun. Salah satu aspek fotosintesis yang sangat sensitif terhadap cekaman kekeringan adalah biosintesis klorofil dan pembentukan protoklorofil 
terhambat pada PA sedikit di bawah 0 atm (Salisbury dan Ross, 1992). Dengan demikian kandungan klorofil total daun dapat dipakai sebagai indikator terjadinya cekaman kekeringan pada jahe seperti pada beberapa kultivar kentang (van der Mescht et al., 1999) dan pada padi IR 64 (Nio, 2010).

Evapotranspirasi menunjukkan jumlah total air yang hilang dari lapangan karena evaporasi tanah dan transpirasi tanaman secara bersama-sama. Faktor-faktor lingkungan yang mempengaruhi evapotranspirasi ialah radiasi matahari, temperatur, kelembaban relatif dan angin. Sedangkan faktor-faktor tanaman yang mempengaruhi evapotranspirasi ialah penutupan stomata, jumlah dan ukuran stomata, jumlah daun, penggulungan atau pelipatan daun, serta kedalaman dan proliferasi akar (Gardner et al., 1991). Ratarata jumlah air evapotranspirasi pada tanaman kontrol lebih besar daripada tanaman yang mengalami kekeringan selama 5 dan 7 hari. Hal ini menunjukkan penggunaan air oleh tanaman yang mengalami kekeringan berkurang pada hari ke-5 dan 7 . Berkurangnya penggunaan air merupakan salah satu mekanisme adaptif untuk mengurangi pengaruh negatif terhadap perkembangan tanaman (Pugnaire et al., 1999; Blum, 2005; Nio, 2009).

\section{KESIMPULAN}

1. Pertambahan biomassa daun pada tanaman jahe kontrol lebih besar daripada tanaman jahe yang mengalami kekeringan selama 7 hari.

2. Cekaman kekeringan selama 7 hari menurunkan kandungan klorofil total daun jahe.

\section{UCAPAN TERIMA KASIH}

Penulis menyampaikan banyak terima kasih kepada Sumarny Patras yang telah membantu pelaksanaan penelitian ini, sehingga dapat berlangsung dengan baik dan lancar sampai selesai.

\section{DAFTAR PUSTAKA}

Blum, A. 1996. Crop responses to drought and the interpretation of adaptation. Plant Growth Reg. 20: 135-148.

Blum, A. 2005. Drought resistance, wateruse efficiency, and yield potential-are they compatible, dissonant, or mutually exclusive? Aust. J. Agric. Res. 56:11591168 .

Bray, E.A. 1997. Plant responses to water deficit. Trend in Plant Sci. 2:48-54.

Darusman, L.K., O. Koswara, J. Wiroatmodjo dan S. Arsjad. 1991. Pengaruh stress air dan $\mathrm{pH}$ tanah terhadap kemungkinan timbulnya senyawaan stress pada tanaman kentang (Solanum tuberosum L.). Forum Pascasarjana 14:13-23.

Fitter, A.H. dan R.K.M. Hay. 1994. Fisiologi Lingkungan Tanaman. Gadjah Mada University Press. Yogyakarta.

Gardner, F.O., R.B. Pearce dan R.L. Mitchell. 1991. Fisiologi Tanaman Budidaya (terjemahan). UI Press. Jakarta.

Jumin, H.B. 1992. Ekologi Tanaman Suatu Pendekatan Fisiologi. Rajawali Press. Jakarta.

Kikuzaki, H. dan N. Nakatani. 1993. Antioxidant effects of some ginger constituents. J. Food Sci. 58:1.4071.410 .

Lakitan, B. 1996. Fisiologi Pertumbuhan dan Perkembangan Tanaman. Rajawali Press. Jakarta.

Lebaschi, M.H., A. Sharifi-Ashurabadi dan D. Mazaheri. 2003. Effect of drought stress on Hypericum perforatum. $J$. Pajouhesh-va-Sazandegi 58:44-51.

Mansfield, T.A. dan C.J. Atkinson. 1990. Stomatal behavior in water stressed plants. Dalam: Alscher dan Cumming (Eds.). Stress Response in Plant Adaptation and Acclimation Mechanisms. Wiley Liss Inc., New York. hal 241-246.

Misra, A. dan N.K. Sricastatva. 2000. Influence of water stress on Japanese 
mint. J. Herbs Spices Med. Plants 7:5158.

Nio, S.A. 2009. Osmotic Adjustment and Solutes in Leaves of Wheat (Triticum aestivum L.) during Water Deficit. Disertasi Doktor. The University of Western Australia. Perth.

Nio, S.A. 2010. Kandungan klorofil total, klorofil a dan b sebagai indikator cekaman kekeringan pada padi (Oryza sativa L.). Jurnal Ilmiah Sains 10: 8690.

Nio, S.A. dan F.E.F. Kandou. 2000. Respons pertumbuhan padi (Oryza sativa L.). sawah dan gogo pada fase vegetatif awal terhadap cekaman kekeringan. Eugenia 6:270-273.

Nio, S.A., S.M. Tondais dan R. Butarbutar. 2010. Evaluasi indikator toleransi cekaman kekeringan pada fase perkecambahan padi (Oryza sativa L.). Jurnal Biologi XIV:50-54.

Pugnaire, F.I., L. Serrano dan J. Pardos. 1999. Constraints by water stress on plant growth. Dalam: Passarakli, M. (Ed.). Handbook of Plant and Crop Stress. 2nd edn, Revised and expanded. Marcel Dekker Inc, New York, Basel.
Salisbury, F.B. dan C.W. Ross. 1992. Plant Physiology. 4rd Ed. Wadsworth Publishing Comapny. California.

Saptarani, E. 1999. Cara Bercocok Tanam secara Vegetatif. Sinar Mas. Jakarta.

Sasmitamihardja, D. 1990. Penuntun Praktikum Fisiologi Tumbuhan. ITB. Bandung.

Srivastata, D.K., V.K. Grupta dan D.R. Sharma. 1994. Regeneration in water stress tolerant callus cultures of tomato (Lycopersicon esculentum L. cv. Solan gol.). Abstr.VIIIth Int. Cong. Plant Tiss and Cell Cult. p. 124.

Tal, M. 1983. Selection for stress tolerance. Dalam: Evans, D.A., Sharp, W.R., Ammirato, P.V., Yamada, Y. Handbook of Plant Cell Culture Volume I-Techniques for Propagation and Breeding. Macmillan Publishing Co. New York. hal 461-464, 472-473.

Upadhyaya, H.K. 1994. Rice production constraints: The importance of waterlimiting factors in east and South-East Asia. Abstr. 7th Meeting of The Int. Prog. Rice Biotech. p.74.

Van der Mescht, A., J.A. de Ronde, F.T. Rossouw. $1999 . \quad$ Chlorophyll fluorescence and chlorophyll content as a measure of drought tolerance in potato. South Africa J. of Sci. 95 (9). 